\title{
PREAMBLE TO SPECIAL ISSUE
}

\author{
City of Melbourne
}

About 15 years ago the City of Melbourne came up with a scheme that would transform completely the face and the fortunes of the city. At the time the city, like thousands of others around the globe, emptied at night as tens of thousands of commuters decamped in their cars for the suburbs. The Council's Postcode 3000 scheme, launched in 1992, outlined plans to entice residential development back into the city, through financial and technical incentives, technical advice, a review of technical requirements, research and statistical data, promotional events and publicity.

It is hard now to believe - walking through the bustling streets lined with converted apartments and thriving businesses - that anyone was ever sceptical about the potential for city living Melbourne-style. The success of Postcode 3000 far exceeded even the most ambitious targets and the City of Melbourne became one of the fastest growing municipalities in the land.

With its visionary new Council House $2\left(\mathrm{CH}_{2}\right)$ building, the City of Melbourne is once again planning a lifestyle revolution. This time the subject is sustainability and the target is the construction industry. Using the $\mathrm{CH}_{2}$ office building as a living, breathing example, the Council intends to demonstrate the potential for sustainable technologies to transform the way we approach the design, construction and indeed entire philosophy of our built environment. Just as Postcode 3000 reinvented the city, the City of Melbourne wants to see the $\mathrm{CH}_{2}$ example copied, improved upon and enthusiastically taken up throughout Melbourne and far, far beyond.

As before, there are a great many sceptics. The City's approach to this has been to patiently press ahead with construction of its best source of proof - $\mathrm{CH}_{2}$ itself - while actively and energetically encouraging lively debate - from the greatest enthusiasts to the harshest critics alike.

\section{$\mathrm{CH}_{2}$ STUDY AND OUTREACH PROGRAM AND THE ACADEMIC CASE STUDIES}

The Study and Outreach Program is a coordinated City of Melbourne effort to consolidate the various opportunities for study, research, documentation and promotion afforded by $\mathrm{CH}_{2}$. It comprises support for academic research, workshops, presentations, site tours, web content and information for students, among other measures.

The case study extracts published for the first time in this journal are among several projects the Council has pursued with academics and universities to drive debate on the case for sustainable development. In time, longer versions of these studies, and others, will be published on the www.ch2.com.au website.
The studies are a fabulous resource but do have some limitations. For instance, they are based on information available on the $\mathrm{CH}_{2}$ design prior to its finalisation, which makes certain descriptions of systems and findings obsolete compared to completed construction by mid 2006. In particular, important changes have already been made to the wind turbines and the heating, cooling and ventilation systems. Furthermore, many of the innovations in $\mathrm{CH}_{2}$ have been subject to limited if any prior academic research. This means the academic knowledge base is small and some of the comparisons made in the papers to prior research findings are arguably akin to comparing apples with pears - interesting but ultimately not the same thing at all.

Some of the studies in this Special Issue of AJCEB make compelling points in favour of the case for sustainable development. Others reflect a more subtle and sometimes overt scepticism that might be encountered in any broad cross section throughout the community. The $\mathrm{CH}_{2}$ team welcomes all of the debate but, over time, ultimately intends to prove the doubters wrong.

Collectively, the studies all demonstrate the enormous value to be gained by researching the case for sustainable development and the scope for a great deal more study and documentation in the field into the future.

\section{INTRODUCING THE $\mathrm{CH}_{2}$ BUILDING AND THE DESIGN APPROACH}

$\mathrm{CH}_{2}$ is a 10 -storey office building for about 540 City of Melbourne staff, with ground-floor retail spaces and underground parking at 218-242 Little Collins Street. It is due for completion by the middle of 2006 .

The building has sustainable technologies incorporated into every conceivable part of its 10 storeys. A sewer water-mining plant in the basement, phase-change materials for reducing cooling energy demands, automatic night-purge windows, undulating concrete ceilings for high thermal mass, a façade of louvres (powered by photovoltaic cells) that track the sun - even the pot plant holders have involved a whole new way of thinking.

Although most of the principles adopted in the building are not new - using thermal mass for improving comfort and reducing energy use, using plants to filter the light - never before in Australia have they been used in such a comprehensive, interrelated fashion in an office building. 


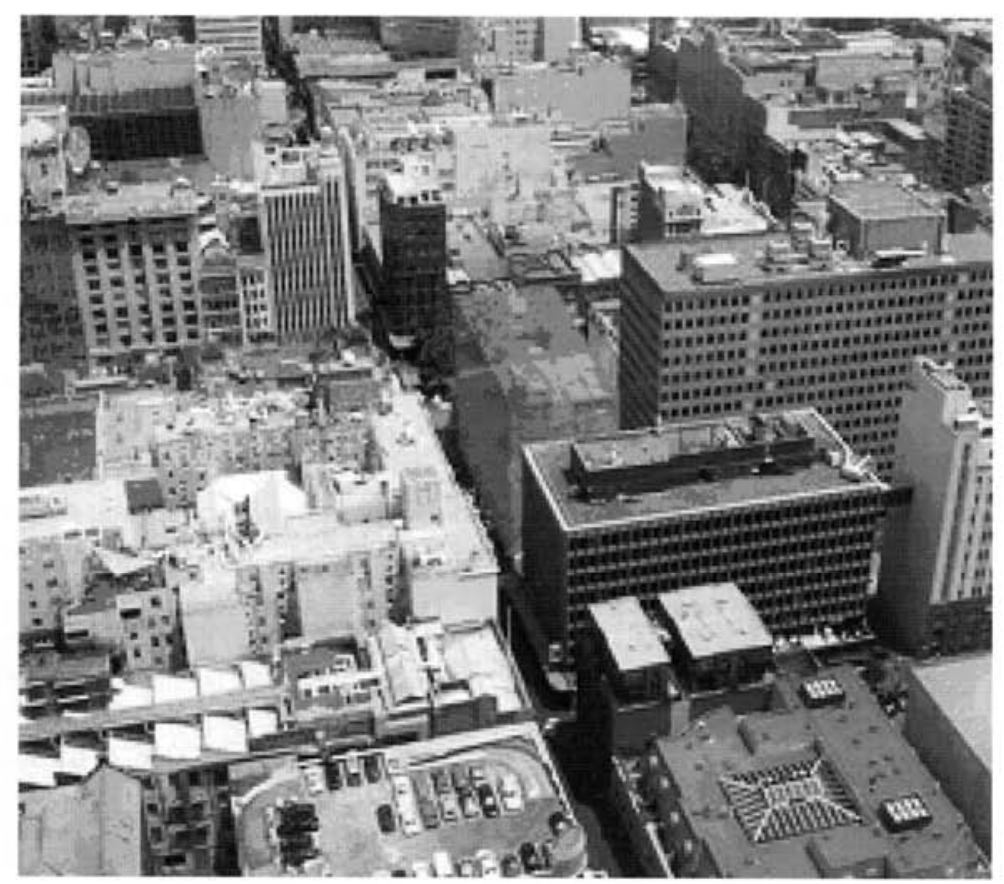

Selected Site for $\mathrm{CH}_{2}$

The gross floor area is $12,536 \mathrm{~m}^{2}$ comprising:

- $1,995 \mathrm{~m}^{2}$ basement areas

- $500 \mathrm{~m}^{2}$ net letable area - ground floor retail

- $9,373 m^{2}$ total net letable

- $1,064 \mathrm{~m}^{2}$ gross floor area - typical floor

- 80 bike spaces

- 9 showers for cyclists

- 20 car spaces. One disabled space. The car park is designed for flexibility of use and can be converted to office space or other uses in the future.

$\mathrm{CH}_{2}$ emissions will be 64 per cent less than a five-star Australian Building Greenhouse Rated building and, when compared to the existing Council House, the building is expected to:

- reduce electricity consumption by 85 per cent;

- reduce natural gas consumption by 87 per cent;

- produce only 13 per cent of the emissions; and

- reduce consumptions of mains supplied potable water 72 per cent.

Sustainable design innovations:

- Australia's first large-scale chilled ceiling installation

- Sewer mining to recover and recycle Class A water from the adjacent public sewer

- World-first phase change material application of its type
- Two-component lighting system for ambient and task needs

- Australia's first application of energy-generating inner-city rooftop vortex wind turbines

- Australia/world third installation of shower towers

- Integrated indoor environment control

- Daytime air conditioning

- Night flushing for thermal mass cooling and energy saving

- Rainwater harvesting and fire sprinkler test-water re-use

$\mathrm{CH}_{2}$ has been designed to reflect the planet's ecology, which is an immensely complex system of interrelated components. Just as it is impossible to assess the role of any part of this ecology without reference to the whole, $\mathrm{CH}_{2}$ comprises many parts that work together to heat, cool, power and water the building, creating a harmonious environment.

For example, in nature, dark colours absorb heat and hot air rises. Accordingly $\mathrm{CH}_{2}$ 's north façade will comprise 10 air extraction ducts covered by dark coloured material that absorb heat from the sun, helping stale warmed air inside the office rise up and out of the building and driving the night purge. The south façade will comprise light-coloured material covering the ducts that draw in fresh air from the roof and distribute it down through the building. Staff will be able to control the flow of this 100 per cent fresh filtered air to their work spaces by floor vents. Louvres made from recycled timber will shade the west facade. Energy from photovoltaic roof panels will power the louvres, which will move according to the position of the sun. Together these features combine to create a controlled and healthy indoor climate to support a more effective work environment. 
wind turbines

roof top energy

The exhaust plenum is at sighty negatios pres. sure. induced by north nues' 'sack-eflect' and wind powered tutbines

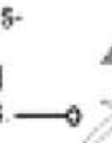

\section{vertical planting}

Green north facate and roct top assists shoding. glare + air qualty

Access to nature enhathees productivity by releving stress.

\section{shading + light}

Light gholf + baloony floces provide horizontal shadiag from northert sun.

Ambient and direct daylight bources off oxtornal and intemal bight sheis?

\section{exhaust}

High level ceiling ex. haust ensures complete emotying of warm aif in ceing spases.

\section{chilled ceilings}

Chiled ociling panels absorb radiated heat. from equament and oc cuparits.

Occupants experience coslth by molating hen to chiled celings over. head

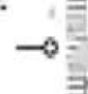

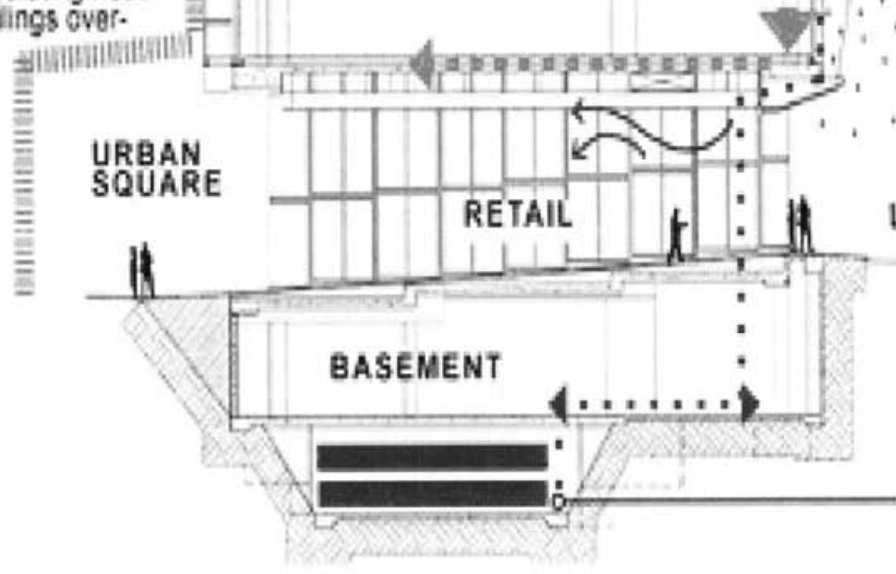

Includes photovolitaic colls, solar hot water panes and a gas-firex co-penerabion plart.

\section{healthy air}

$100 \%$ outside air supply via vertical ducts dether a floos by floor to sealed actess floot plenum.

\section{thermal mass}

Themal mass in woncrete siab absores excess heast from the space.

displacement air

Fresh ar fed at low speed through centro la ble flocr vents
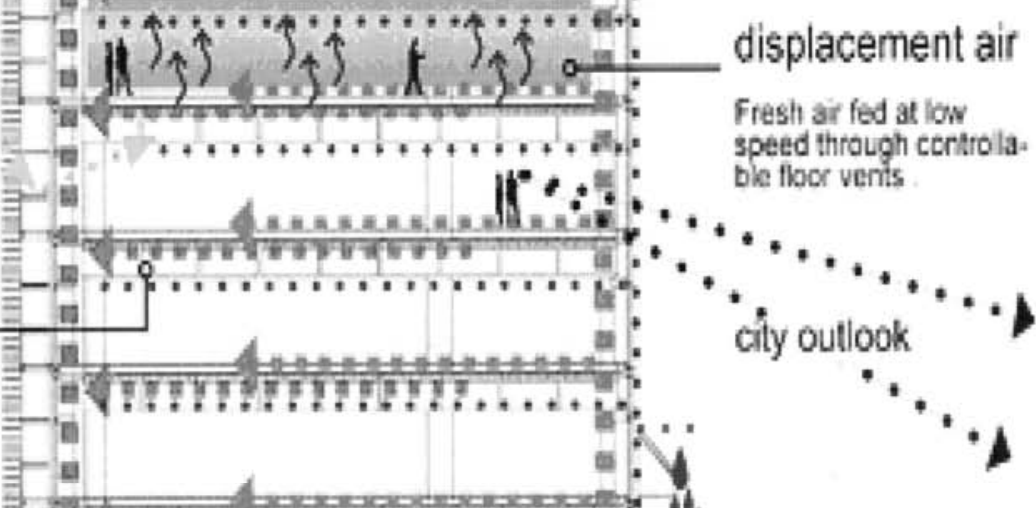

\section{shower towers}

Air and water falis to provide cool water for buiding enticulaben and cosol air to supolement ground floor and relail cooling.

LT COLLINS ST

phase change material

Waler is piped to phase change plant for récool. ing

\section{BIO CLIMATIC SECTION}




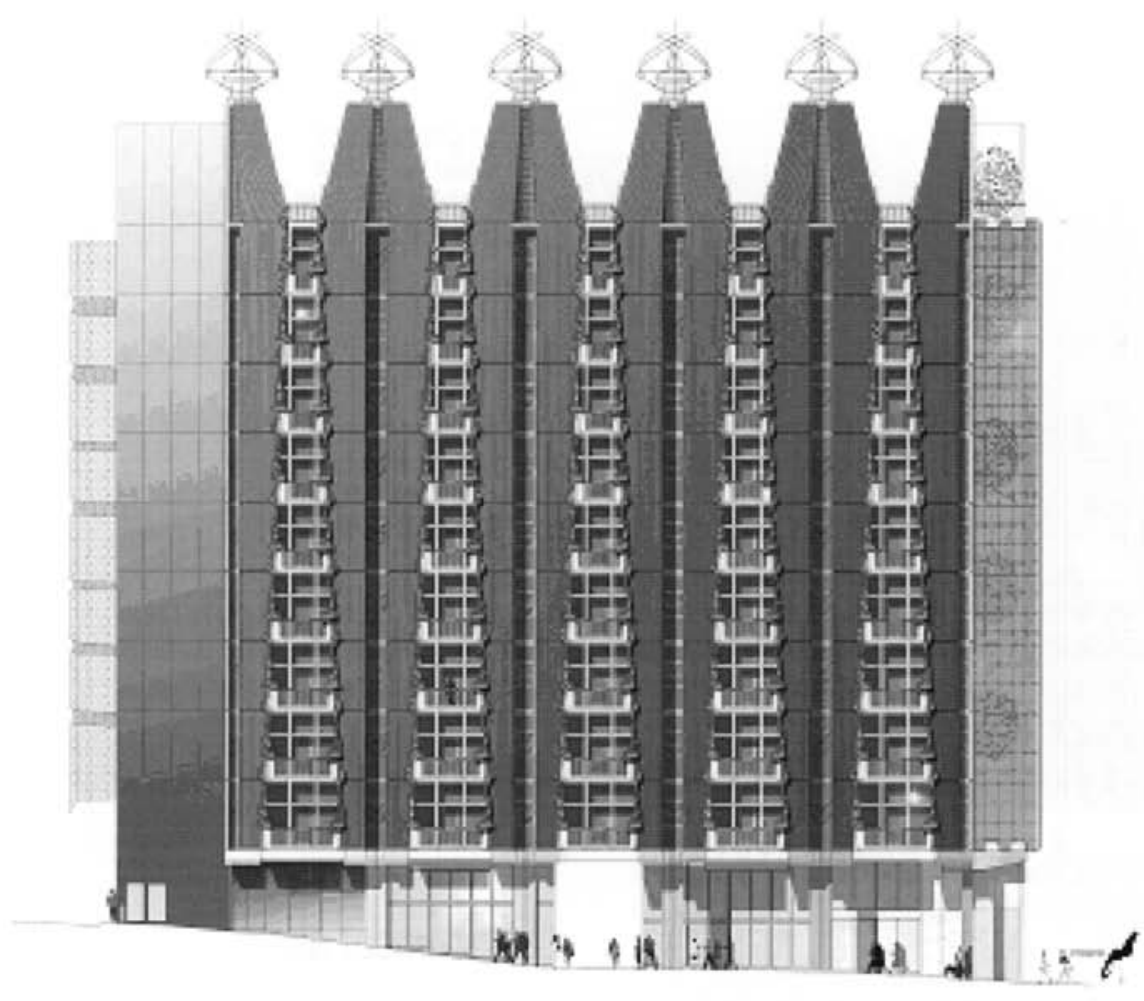

a. Diagrammatic North Elevation

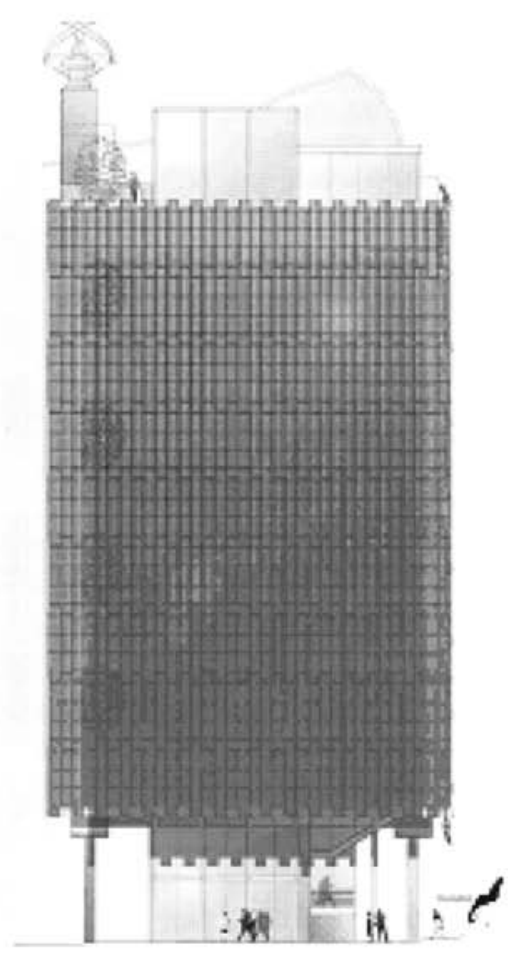

b. West Elevation showing

North (a) and west (b) elevations show how the bio climatic design response has determined the design resolution for each façade.

About 100,000 litres of high quality Class A water will be extracted from the sewer in Little Collins Street a day. A city sewer usually holds 95 per cent water, a burden on the system and a massive waste of water. The sewage, along with any generated on site, will be processed through a multi-water treatment plant that will separate out clean water and return the waste back to the sewer. The extracted water will only be used for non-drinking and nonhuman contact uses, although it is pure water that is quite safe to drink since it is graded Class $\mathrm{A}$ by the Environment Protection Authority.

Some of the recovered water will supply $\mathrm{CH}_{2}$ 's water cooling, plant watering and toilet flushing needs. The rest will be used in other council buildings, city fountains and plants. Additional water will be saved through recycling water from the fire-safety sprinkler system and from rainwater.

\section{DESIGN PROCESS AND APPROACH}

The fundamental design concepts for $\mathrm{CH}_{2}$ were developed by an integrated design team over a two-week period in January 2002. During this two-week charrette process, consultants were paid for their time on top of their tendered and accepted fees to complete the work.

After the charrette, the design continued to be developed by individual companies as members of a highly collaborative $\mathrm{CH}_{2}$ design team that shared emerging design documentation weekly. The companies charged fixed fees over a 12-month period and conducted weekly design meetings for eight months to resolve design and construction issues. Construction work on the 10-storey building began in early 2004 .

In addition to appreciating the value that a collaborative and integrated design process brings to the success of a sustainable building project, it is also important to understand the central design approach. There are five essential aspects that define the design approach for any building that intends to be based on ecological and bioclimatic principles: local micro-climatic conditions (daily and annual temperature variations, wind and rain frequency and intensity, solar access); site factors (shape, geology, hydrology); ecological sustainability objectives and goals; human physiology or the way the human body works; and technologies and techniques.

For example, it is the micro-climatic analysis that drove the decisions about the ability to use $\mathrm{CH}_{2}$ 's building fabric as thermal mass and night purging as part of the cooling and energy saving strategy. The micro-climate of inner-Melbourne also determined the amount of glass exposure for natural lighting and thermal performance, solar protection requirements and energy and rain water harvesting opportunities.

\footnotetext{
4 The Australian Journal of Construction Economics and Building [Vol 5, No 2]
} 


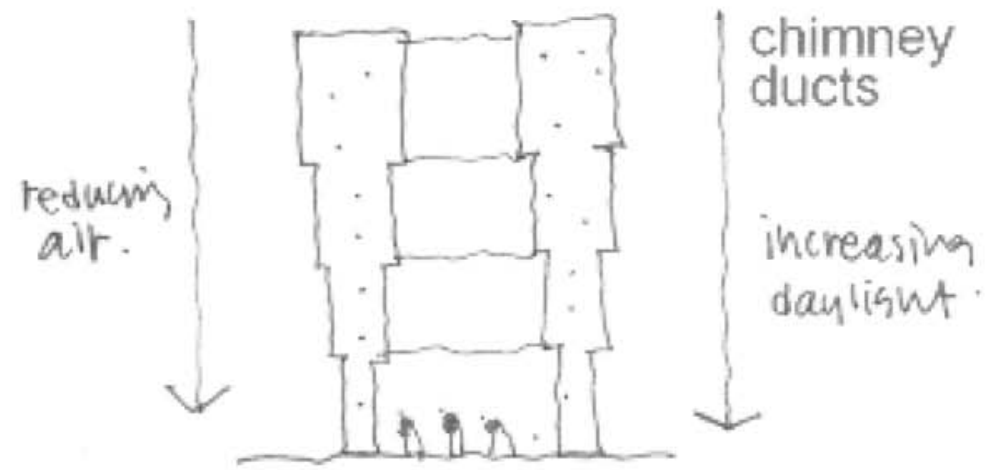

Image from the initial workshop of the ventilation air supply and window concept

Site factors such as the long rectangular proportions of $\mathrm{CH}_{2}$ 's location dictated a 'deep space' floor plate, which presented special design challenges in terms of natural lighting and space conditioning. $\mathrm{CH}_{2}$ 's selected site, therefore, dictated a design approach that did not use natural ventilation during the day as this was unlikely to be possible with the depth of floor plate. The inner-city location also drove a design that resulted in increased window sizes descending down the building as these allow greater amounts of natural light to enter at the lower levels.

An equally important aspect influencing the $\mathrm{CH}_{2}$ team's approach to the design was the establishment of clear ecological sustainability objectives and goals directed at reducing energy and water use, emissions and waste.

Creating a healthy work environment for the building's occupants has also been paramount to the $\mathrm{CH}_{2}$ team, which has required a design approach that responds directly to the way the human body works. Although seemingly obvious, it can sometimes be forgotten by building designers that offices are ultimately places for people to work. Consideration of human physiology directs designers to reconsider heating and cooling strategies, ventilation requirements and sensory stimulation to maintain natural biological health.

Humans are hot-blooded mammals. They release heat into the office environment at rates depending upon their activity and this must be removed by the building's space-conditioning system. People feel hot or cold depending on the way they dress. Their skin acts as an evaporative cooling system, which is sensitive to air humidity and movement. Human skin is also more sensitive to the temperature of surfaces surrounding occupants that radiate or absorb heat, in comparison to a less direct response to contact with the air surrounding their body. This human physiological condition has directed the $\mathrm{CH}_{2}$ design team to develop an approach that responds by cooling with chilled ceiling panels and passive cooling using exposed concrete ceilings that absorb heat during the day.

The $\mathrm{CH}_{2}$ team's design approach has resulted in a cooling technique and technology that uses water circulated through radiant absorption ceiling panels rather than a system that relies on air for cooling, as is traditional in office buildings and which requires large volumes of chilled air to be produced. This approach to the design of $\mathrm{CH}_{2}$ 's ventilation system means the air supplied to occupants is specifically for breathing, which has eliminated the need to expend large amounts of energy cooling air. The radiative cooling approach has also created a situation where air temperatures are not as important to achieve comfort levels. With this, the $\mathrm{CH}_{2}$ team is helping establish a new standard definition of comfort level, which combines air temperature and radiant cooling to produce a resultant temperature, as has been achieved in Denmark.

\section{GREEN STAR RATING}

The $\mathrm{CH}_{2}$ project was the first in Australia to achieve six stars under the Green Building Council of Australia's new Green Star certified rating tool, where the minimum rating is one star and the maximum is six. This achievement is also significant as the design for the project started prior to the launch of the Green Star Rating System and Green Star - Office Design.

The Green Star rating system evaluates the environmental design and performance of Australian buildings based on a number of criteria, including energy and water efficiency, the quality of indoor environments and resource conservation.

\section{ENVIRONMENTAL FEATURES}

Fresh air: Instead of supplying the office spaces with about $85 \%$ recirculated air, as is normal in typical variable air volume air conditioning systems for office buildings, $\mathrm{CH}_{2}$ will not recycle any air. All the air supplied to the office spaces will be $100 \%$ filtered fresh air drawn from roof level, supplied via the south ducts and exhausted via the north ducts.

Indoor air pollutants: Many products emit toxic gasses for months or years after construction and significantly reduce indoor air quality. All materials used in $\mathrm{CH}_{2}$ are being subjected to a full environmental audit to ensure, among other things, that low volatile organic compound materials are used in products such as carpets paints, adhesives and sealants.

Potable (drinking) water: About 25 per cent of potable (drinking) water will come from the sprinkler system used for fire safety. Safety regulations require that sprinkler systems are tested regularly and this involves discarding large quantities of clean drinking water. In $\mathrm{CH}_{2}$ this water will be collected and used.

Natural Light: Lower floors generally receive less daylight than upper floors so windows on the north and south facades will be larger on the lower floors than the upper ones. This allows the total amount of glass to be minimized, thus reducing energy loss, while maintaining desirable natural light levels. Sensors will monitor the amount of daylight coming in and adjust the artificial light required accordingly.

Artificial lighting: The level of ambient artificial light will be low and will be supplied by low-energy T5 fittings linked to sensors that will reduce the light when sufficient daylight is available. However it will be supplemented with individually controlled lamps at workstations to give occupants more control over their environment. Thus the level of lighting on a floor or in an area will reflect the level of activity. 
Light shelves: Light shelves on the north façade will reflect sunlight onto ceilings and produce a soft indirect light, reducing artificial lighting requirements. The light shelves are internal and external and made of perforated steel. Sensors will increase and decrease the artificial lighting according to the amount of sunlight being reflected into the building; thus a balance of natural and artificial light will be achieved.

Vertical gardens: The north-facing facade will comprise steel trellises and balconies supporting a series of vertical gardens nine storeys high. The foliage will help protect the building from the sun and filter sunlight to reduce glare indoors.

Louvres: The entire west facade of $\mathrm{CH}_{2}$ is protected by a system of timber louvres that pivot with the sun to be fully open in the morning and closed for the full sun in the afternoon. The louvres will be made from recycled timber and will be controlled by a hydraulic system that moves the panels through a six-hour open and close cycle.

\section{COOLING AND HEATING}

Much effort has been invested in ways to cool, rather than heat, the building. This is because human activity and electronic equipment give off vast amounts of heat.
In $\mathrm{CH}_{2}$, fresh outside air will be drawn in from 17 metres or more above the street and channelled into shower towers on the southern side. As air falls within the towers it will be cooled by evaporation from the water shower. The cool air will be channelled to the shops below and the cool water supplied to a phase change material (PCM) tank in the basement.

This PCM tank will be much like a battery that stores coolness, or 'coolth'. Water cooled by the towers will travel through the tank, freezing the battery. A separate water stream will pass through the battery to be chilled, through chilled ceiling panels and beams to cool the building, and then back into the battery to begin again.

Cool water running through chilled panels fixed to the ceiling - and chilled beams in front of the windows - will create gentle radiant coolness that will descend into the workspace at about $18^{\circ} \mathrm{C}$. This will replace traditional systems that use fans to blow colder recycled air directly at occupants.

Meanwhile, natural ventilation will cool the building at night. Windows on the north and south façades will open to allow fresh cool air to enter the offices, flush out warm air and cool the exposed ceilings of the building. This is called night purging. Sensors will close the windows when they detect high winds and rain or higher temperatures.

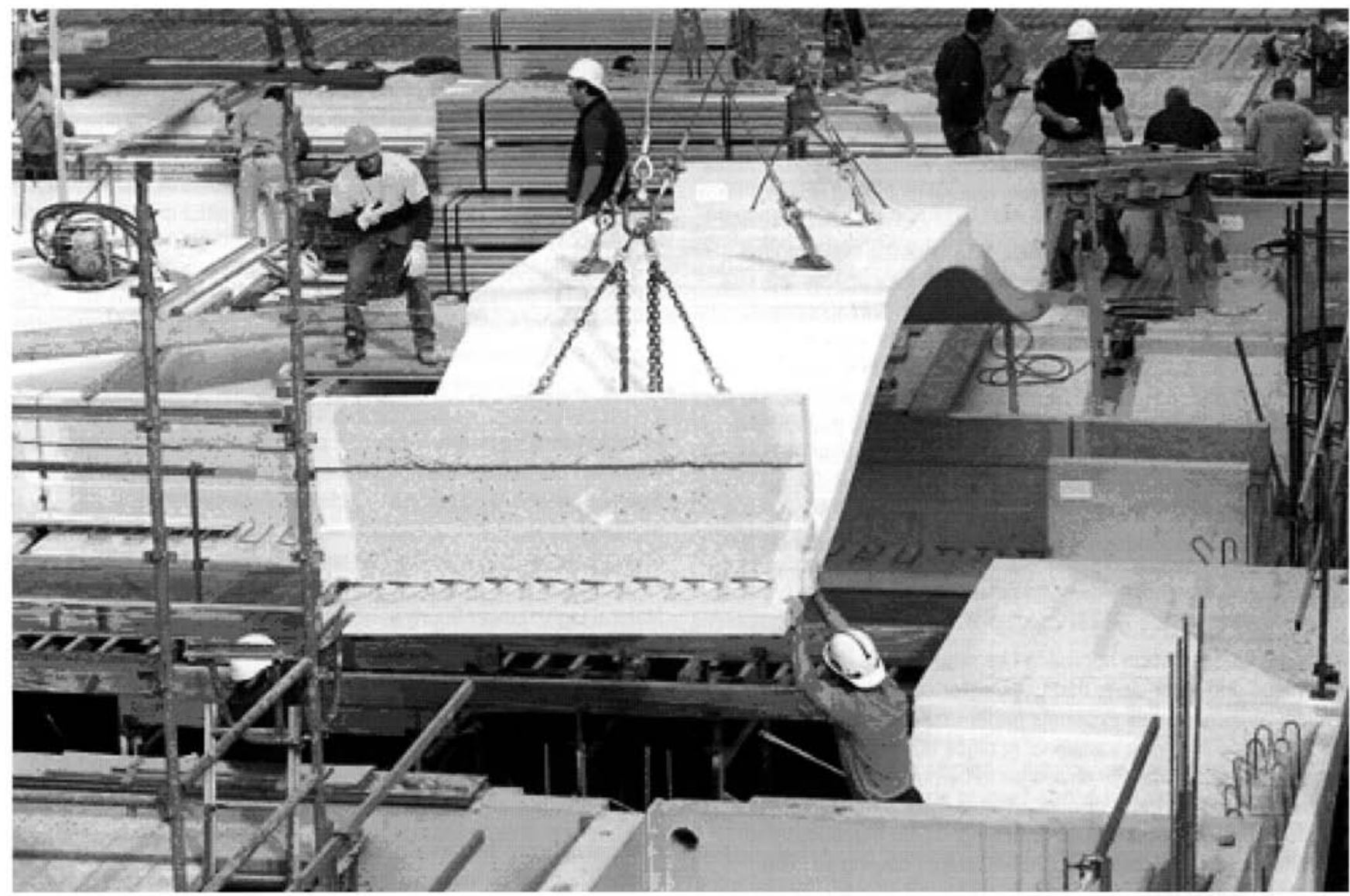

On-site insertion of a precast concrete curved beam ceiling panel 
Outside air from the night purge will cool the $180 \mathrm{~mm}$-thick precast concrete ceilings that store this coolness due to their high thermal mass. In much the same way as a cement wall retains heat long after the sun has set, this 'coolth' absorbs heat radiated from people and electrical equipment during the day and will contribute to the cooling needs of the offices, thereby reducing air conditioning plant load by up to 14 per cent in summer.

\section{PAYBACK PERIOD}

$\mathrm{CH}_{2}$ 's environmental features are estimated to pay for themselves within 10 years when compared with a conventional building. However $\mathrm{CH}_{2}$ 's wider value is as an example for others to copy.

Compared with the existing Council House (located next door on Little Collins Street), $\mathrm{CH}_{2}$ will reduce its electricity consumption by 85 per cent and its natural gas consumption by 93 per cent.

This means $\mathrm{CH}_{2}$ will use only 13 per cent of the energy consumed by the existing Council House.

Although the reduction in energy costs will be substantial, the greatest economic benefit is expected to be in increased staff effectiveness at work, reduced absenteeism and lower staff turnover rates, which cost employers millions of dollars each year.

\section{PRINCIPAL CONSULTANTS}

City of Melbourne (Design and Project Management)

Designlnc (Architectural Design and Documentation)

Lincolne Scott (Services Engineering)

AEC (Advanced Environmental Concepts)

Bonacci Group (Structural AND Civil Engineering)

Marshall Day (Acoustics)

Donald Cant Watts Corke (Quantity Surveying)

Hansen Yuncken (Builders)

\section{WEB REFERENCES}

www.ch2.com.au, which is a direct link to the $\mathrm{CH}_{2}$ pages on www. melbourne.vic.gov.au 